\title{
Karantinada Dasein Olmak: Homemade Antoloji Serisine Heideggerci Bir Okuma
}

\author{
YASEMİN ÖZKENT* \\ yaseminozkentt@gmail.com \\ ORCID ID: 0000-0002-8617-8429
}

\begin{abstract}
Öz: Homemade (2020) isimli kısa film antolojisi koronavirüs pandemisi nedeniyle neredeyse tüm dünyanın karantinada olduğu sırada Netflix tarafından yayınlanmıștır. Farklı yönetmenler tarafından çekilmiş on yedi kısa film, birbirinden bağımsız hikâyelerinden oluşmaktadır. Filmler, pandemi kriziyle birlikte yaşanan "kaygı", "korku", "endişe", "yalnızlik" ve "ölüm" gibi varolusssal temaları, sanatsal bir dille ifșa etmektedir. Bu düşüncelerden yola çıkan çalışmada Homemade'in, Martin Heidegger'in felsefesini bir eylem olarak açığa çıkaran anlatı yapısına sahip olduğu ileri sürülmektedir. Bu doğrultuda, Homemade örneklemi üzerinden Heidegger'in varoluşsal ontolojisinin özcü temalarının bulgulanması amaçlanmaktadır. Çalıșmada, Heidegger'in ontolojisi, pandeminin olușturduğu kriz ortamındaki insanın duygu ve düșünce dünyasındaki değişimlerle ilişkilendirilmiștir. Kısa filmler, Heidegger'in varlı̆̆ anlama minvali olarak temellendirdiği Dasein kavramı ekseninde değerlendirilmiştir. Dasein olmanın temel ereklerinden "dünya-içinde-varlık", "kaygl-duyan-varllk" ve "ölüme-doğru-varlık" üzerinden karantina ve pandemi süreci tahlil edilmiştir. Bu bağlamda karantinanın, her günkü Dasein'ın kendi varlı̆̆ının en zati imkanını açığa çıkardığı savunulmaktadır. Dasein izole bir şekilde yaşarken, başkalarıylabirlikte-varolduğunu bilerek kendi varoluşunu tesis etme yoluna girmiştir.
\end{abstract}

Anahtar kelimeler: Koronavirüs, Martin Heidegger, Dasein, Antoloji Serisi, Homemade

\section{Giriş}

Koronavirüs pandemisinin başlamasıyla gerçekleşen küresel krizin etkilediği alanların başında sinema ve televizyon sektörü gelmektedir. Netflix, pandemi krizine orijinal içerik olarak ürettiği bağımsız filmlerle çözüm bulmuştur. On yedi farklı yönetmenin çektiği kısa filmlerden oluşan Homemade $(2020)^{1}$ isimli antolo-

\footnotetext{
${ }^{*}$ Dr. Öğr. Üyesi, Selçuk Üniversitesi, İletişim Fakültesi.

${ }^{1}$ Homemade antoloji serisinde yer alan filmler sırasıyla şöyledir: Ladj Ly (Ladj Ly, Fransa), Voyage Au Bout De La Nuit (Paolo Sorrentino, İtalya), The Lucky Ones (Rachel Morrison, ABD), Last Call (Pablo Larraín, Şili), Couple Splits Up While In Lockdown LOL (Rungano Nyoni, Portekiz), Espacios (Natalia Beristáin, Meksika), Casino (Sebastian Schipper, Almanya), Last Message (Naomi Kawase, Japonya), Ferosa (David Mackenzie, İskoçya), Penelope (Maggie Gyllenhaal, ABD), Mayroun and the Unicorn (Nadine Labaki ve Khaled Mouzanar, Lübnan), Annex (Antonio Campos, ABD), Johnny Ma (Johnny Ma, Meksika), Crickets (Kristen Stewart, ABD), Unexpected Gift (Gurinder Chadha, Londra), Algoritmo (Sebastián Lelio, Şili), Ride It Out (Ana Lily Amirpour, ABD). İtalyan-Şili ortak yapılı olan proje, Pablo Larraín, Juan de Dios Larraín ve Lorenzo Mieli tarafından tasarlanmıştır. https://www.netflix.com/title/81285512.
} 
ji serisini ${ }^{2}$, neredeyse tüm dünyanın eve kapandığ zamanlarında yaratıcı film yapımcılığına iyi bir örnek teşkil eden Homemade, çoğunlukla cep telefonuyla ya da evde bulunan kameralarla çekilmiş filmlerden oluşmaktadır. Drone kamera kullananlar dışında yönetmenlerin çoğu filmlerini evinde, evinin bahçesinde, balkonunda ya da çevresinde çekmiştir. Kısa film serisinin farklı yönetmenleri bir araya getirmesi ve yönetmenlerin karantinadaki ortak yaşam deneyimlerini öznel bakış açısıyla yorumlamaları, uluslararası sinema alanında oldukça ufuk açıcıdır.

Kısa filmlerin yönetmenlerine tematik bir sınırlama getirilmemesine rağmen filmlerin hepsi pandemiyle ve karantinayla ilişkili birer hikâye anlatmaktadır. Aile hayatı, zaman geçirme etkinliği, pandeminin çocuklar üzerindeki etkisi ya da varoluş idesi filmlerin odaklandığı konulardır. Karantina sürecinde yaşanan ritüeller neredeyse her filme yerleştirilmiştir. Esasen küresel bir şirketin aynı anda dünyayı etkilemek için yaptığı küresel bir girişim olan Homemade, pandemi üzerine evrensel bir dil yakalamayı başarmıştır. Kısa filmlerin birçoğu günlük rutininde kendi varoluşunu sorgulamayı çoğu zaman düşünmeyen insanın, karantinayla birlikte girdiği varoluş sorgulamasının altını çizmektedir. Bu yönüyle filmleri felsefi düşünmede bir müttefik olarak görmek olanaklıdır. Robert Sinnerbrink'in de belirttiği üzere sinemaya, bir temsili indirgeme aracı olarak tasarlanmış kaynak olarak yaklaşılabilir. Filmler, varlığın hakikatini şiirsel bir yolla açığa çıkarma deneyimidir. Sinemanın gerçeklikle ilişkisini Andre Bazin, zamanın ve bilincin özetlenmesi, Siegfried Kracauer fiziksel gerçekliğin karşılık bulması, Walter Benjamin elverişli olanın bilinçsizce açığa çıkarılması, Gilles Deleuze hareket ve zaman birleşimiyle düşünce ve görüntülerin algılanması ve Martin Heidegger gerçeğin yaratıcı bir biçimde ifşa edilişi olarak açılar. Bir bakıma sinema, sanal ve kurgusal dünyalar inşa ederek dünya-içinde-varlığın farklı yönlerini ortaya çıkarır. ${ }^{3} \mathrm{Bu}$ anlamda Homemade, Heidegger' in yaklaşımıyla bir "açı̆̆a çıkarma" fenomeni olarak görülebilir. Nitekim Heidegger "The Turning” (1971) adlı makalesinde sinemayı bir imge biçimi olarak gördüğünü ifade eder. ${ }^{4}$ Bu doğrultuda kısa film serisi, hakikati alışılagelmişin dişında teknolojik aracılarla aktarması ve hayal gücünün olanaklarını kullanması bakımından Heidegger’in "şiirsel düşünme"5 kavramını uygulamak için iyi bir örneklemdir.

Koronavirüs pandemisine ontolojik varoluşçu bir perspektiften bakmak, bu kadim sorgulama biçiminin bilim ve teknoloji çağında yol göstericiliğini ortaya koyar. Kitlesel ölümlerin söz konusu olduğu pandemi sürecinde "varolma"nın an-

\footnotetext{
2 Antoloji serisi, birbiriyle örtüşen bir tema çerçevesinde geliştirilen hikâyelerden oluşmaktadır. Televizyonun altın çağı olarak kabul edilen 1950’li ve 1960’lı yıllarda oldukça popüler bir anlatı biçimidir. Daniela M. Schlütz, "Contempoary Quality TV: The Entertaintment Experience of Complex Serial Narratives", Annals of the International Communication Association, 40/1 (2015), s.96.

${ }^{3}$ Robert Sinnerbrink, “Techne and Poiesis: On Heidegger and Film Theory”, Tēchne/Technology, Researching Cinema and Media Technologies Their Development, Use, and Impact, der., Annie van den Oever, Amsterdam, Holland: Amsterdam University Press, 2014, s.77.

${ }^{4}$ Martin Heidegger, "The Turning”, çev., Kenneth R. Maly, Research in Phenomenology, 1 (1971), s.15.

${ }^{5}$ Heidegger bu kavramı The Question Corcerning Technology and Other Essays (1977) adlı kitabında kullanır. Kavram aracıllı̆ıyla şeylerin kendi gerçekliklerinin güzel sanat aracılığıyla açığa çıkarılmasını ifade eder. Martin Heidegger, The Question Corcerning Technology and Other Essays, çev., William Lovitt, New York \& London: Garland Publishing, 1977, s.34-35.
} 
lamını sorgulamak, hayata değer atfetmenin ve bir tür meditasyon yapmanın yolu gibi görünmektedir.

Bu düşüncelerden yola çıkılarak oluşturulan çalışmada Homemade isimli antoloji serisinde, Heidegger'in varoluşsal ontolojisinin temaları araştırılmıştır. Heidegger'in ontolojisi koronavirüs pandemisinin oluşturduğu kriz ortamındaki insanın duygu ve düşünce dünyasındaki değişimlerle ilişkilendirilmiştir. 20. yüzyılın en etkili filozoflarından olan Heidegger'in felsefesini sinemasal alanda sorgulamaya niyetlenildiğinde ilk karşılaşılan fenomen "varlık nedir?” sorusudur. Çünkü Heidegger, insan olmayı fenomenolojik bir yaklaşımla ele almıștır. Bir diğeri varlığ 1 anlama minvali içinde varolan Dasein'dır. Kısa film serisi Heidegger'in ${ }^{6}$ "kendi varlığı içinde kendini şu veya bu suret ve açıklıkla anlayan, bizatihi varlık anlayışına sahip olan”, "öteki varolanlara göre ve ontik olarak müstesna" olarak açıkladığı Dasein kavramı aracılığıyla değerlendirilecektir. Çalışma, Dasein’ın temel erekleri üzerinden karantinada olma durumunu tahlil etmektedir. Bunlar, "dünya-içinde-varlık", "birlikte-varlık", "kaygı-duyan-varlık" ve "ölüme-doğruvarlık”tır. Dünya-içinde-varlığı ve birlikte-varlığı anlamak için birincil olarak sorgulanması gereken Dasein'dır. Bu yüzden çalışmanın ilk başlığının girizgahını Dasein kavramı ve karantinada Dasein olmanın belirtileri oluşturmaktadır. Sonrasında "kaygı-duyan-varlık", aletheia kavramı ve içinde-var-olmaklıkla ilişkileri çerçevesinde ele alınmıştır. Son olarak Dasein'ın bütün-olma-imkanının ontolojik konstitüsyonu olan “ölüme-doğru-varlık” olması üzerinde odaklanılmıştır. Bu başlık altında Dasein’ın kendi varlığının farkına varmasını açıklayan "otantik” kavramına da değinilmiştir.

\section{Amaç ve Yöntem}

Doğal sistemlerin Sinema ve felsefe çalışmaları iç içe geçmiş iki fikir etrafinda toplanmıştır. İlki dünyaca tanınan filozofları tanıtmak, ikincisi ise yerleşik ya da görece daha az bilinen felsefi konuları kullanarak sinemayı felsefeyle anlamanın yeni yollarını aramaktır. ${ }^{7} \mathrm{Bu}$ çalışmada ikinci yol izlenecektir. Çalışmanın örneklemini karantina döneminde Netflix platformunda yayınlanmak üzere üretilen Homemade isimli kısa film antolojisi oluşturmaktadır. Homemade’in karantina sürecine yönelik felsefe yapan bir yaklaşıma sahip olması ve felsefi bir bağlam içinde okunabilirliği örneklem olarak seçilmesinde etkili olmuştur. Kisa filmler, Heidegger'in varoluşsal ontolojisinin temaları çerçevesinde incelenmiştir. Çalışmanın amacı Heidegger'in varoluş ontolojisini, koronavirüs pandemisinde üretilen Homemade antoloji serisi aracılığıla bulgulamaktır. Heidegger’in varlığı anlamada başvurduğu temel kavram "Dasein olma" ve karantinada olma durumu iliş̧isi, kısa filmler üzerinde tartışılmıştır. Bir bakıma çalışma karantina-sinemafelsefe ilişkisi üzerine çıkarım yapmayı amaçlamaktadır. Bu doğrultuda belirlenen araştırma soruları şöyle sıralanabilir:

- Bir film, felsefi bir kavramı anlamaya nasil aracı olur?

\footnotetext{
${ }^{6}$ Martin Heidegger, Varlık ve Zaman, çev., Kaan H. Ökten, İstanbul: Agora Kitaplığı, 2008, s.12.

7 David Martin-Jones, "Introduction: Film-Philosophy and a World of Cinemas", Film-Philosophy, 20/1 (2016), s.12.
} 
- Koronavirüs pandemisinin insanın düşünce ve duygu dünyasındaki oluşturduğu değişimi, Homemade’i Heidegger'in varoluşsal ontolojisiyle değerlendirerek anlamlandırmak mümkün müdür?

Çalışmada bir filmi felsefi bir düşünceye dönüştürürken izlenilen yol ise şöyledir: Öncelikli olarak sinemanın açıkça aktardıklarının yanında düşünme yetisini kullanarak çok sayıda ilginç göndermeler yapması, bir filmin felsefi olarak okunabilmesinin yolunu açar. Bazı filmler felsefeyle olan bağlantısını açık bir biçimde kurarken bazılarını anlamak zorlu bir süreçtir. Nitekim felsefe soyut bir süreçken, sinema görsel imgelerden oluşur. Bernd Herzogenrath'ın belirttiği üzere bir filmi felsefi olarak incelemek geniş bağlamda ele almayı gerektirir. Öncelikli olarak görüntü aracılığıyla düşünmenin olup olmayacağı sorgulanmalı, sonrasında felsefi düşüncelerle bilimsel analizi ilişkilendirme yolu izlenmelidir. ${ }^{8}$ Sinema-felsefe bağlantısı kurarken hem yerel ve küresel sinematik eklemlenmeleri, hem de karmaşık şekilde birbiriyle ilişkili felsefi yaklaşımları bir arada düşünmek gerekmektedir. ${ }^{9}$ Bu noktada dikkat edilmesi gereken bir diğer husus da görüntünün tek açıklayıcı olmadığını göz önünde bulundurmaktır. Görsel imgeleri felsefi fikirlerle somut bir şekilde değerlendirmek, felsefi konuların ve kaygıların gündelik yaşantıya nasıl eklemlendiğini gösterir. Sinemada felsefi fikirler, temalar ve perspektifler karakter, olay örgüsü, durum temsilleri ve diyaloglar aracılığıyla açığa çıkarılır. ${ }^{10}$ Çalışmanın bundan sonraki kısmında bahsedilen parametrelerden yola çıkılarak Heidegger'in Dasein kavramı kısa filmler aracılığıyla değerlendirilmiştir.

\section{Dasein'ın Ontolojik Varoluşu}

Martin Heidegger'in insanın varoluşunu sorguladığı Varlık ve Zaman (1927) adlı kitabında başvurduğu temel kavram Dasein'dır. ${ }^{11}$ Heidegger'e göre her şeyin temeli olan varlık, konuştuğumuz, kanaat beslediğimiz ya da ilişki kurduklarımız olabilir. Varlık, ancak ontolojik öncellikte kavranabilir, tüm insanları kasteden bütünsellikle ve birlikle açıklanabilir. Varlığın ne olduğu, nedenselliği, nasıllığı, gerçekliği, mevcudiyeti, kalıcılığı ya da geçerliliği Dasein'da yatmaktadır. ${ }^{12}$ Heidegger, Dasein aracılığıla kartezyen geleneğin tarihten ve toplumdan yalıtılmış inşa ettiği insan anlayışını değiştirmiştir. Dasein toplum içinde varolur, dolayısıyla başkalarıyla-birliktelik fenomenine yakın hareket eder. İnsan ancak ötekilerle hareket ettiğinde, diğerlerinin ruh hallerini paylaştığında ve sosyalleştiğinde Dasein olur ya da Dasein’ı ele geçirir. Bir bakıma Dasein,

\footnotetext{
${ }^{8}$ Bernd Herzogenrath, "Introduction. Film and/as philosophy: An elective affinity?", Film as Philosophy, der., Bernd Herzogenrath, London: University of Minnesota Press, 2017, s.viii.

${ }^{9}$ Martin-Jones, “Introduction”, s.17.

${ }^{10}$ Christopher Falzon, Philosophy Goes to the Movies: An Introduction to Philosophy, London \& New York: Routledge, 2002, s.5.

${ }^{11}$ Almanca kökenli bir sözcük olan Dasein, insan varlığı anlamına gelmektedir. Heidegger kavrama felsefi anlam yükleyerek, felsefesinin temel kavramlarından biri olarak kullanır. Dasein, "da" ve "sein" sözcüklerinden türetilmiştir. "Da" burada ve orada; "sein" ise varolmak ve varoluş anlamlarına gelmektedir. "Dasein" burada ve orada olan varlıktır. Bir bakıma Dasein, varlığın anlamını sorgulayan tek varlıktır. Abdulkadir Çüçen, Heidegger'de Varlık ve Zaman, Bursa: Asa Kitabevi, 2003, s.39. Heidegger'in özellikle bu kavramı tercih etmesi, varoluş sorgulamasında en kapsayıcı kavram olmasından kaynaklanmaktadır. İnsanın varoluşu konusundaki diğer tüm kavramlardan farklı olan Dasein, insanın çokyönlülüğüne atıf yapar. Watts Michael, Heidegger a Guides For Beginner's, London: Hodder \& Stoughton, 2001, s.25.

${ }^{12}$ Martin Heidegger, Varlık ve Zaman, çev., Kaan H. Ökten, İstanbul: Agora Kitaplı̆̆ı, 2008, s.6.
} 
başkalarıyla-birlikte-olmaktır. Daha ilk doğduğu andan itibaren başkalarının yaptığını yapmaya başlayan bebek Dasein'ı ele geçirir. Normlara uyma, Dasein'in temel unsurlarındanken; birilerinin yaptığını yapma Dasein’n benliğidir. ${ }^{13}$

Heidegger, Dasein’n karakterinden iki çıkarım yapar. Bunlardan ilki "söz konusu varolanın özü, onun bir-şey-olmasında yatar"; ikincisi "söz konusu varolanın kendi varlığı, içinde kendine mesele ettiği varlık hep benimkidir." Heidegger, geleneksel anlamda varoluşun ontolojik anlamının Dasein’ın özüne neden uygun olmadığını, Dasein’’n özünün kendi varoluşunda yatmasıyla ilişkilendirmiştir. Bu varlığın karakteri bir görünüme sahip özellikler değil, kendisine ait varolma imkanıdır. Başka bir deyişle Dasein’ın ismi masa ya da ağaç gibi bir nesnenin neliğini ifade etmeyi değil, varlığını ifade etmeyi amaçlamaktadır. ${ }^{14}$ Dasein öznenin içeriği olmadığı için varoluş yapısı antropolojik, psikolojik ve biyolojik yorumlardan ayrılır. Dasein; cotigo, ego, ruh, özne ve kişi değil, varlığın insanlığını açığa çıkaran "insanlık"tır. ${ }^{15}$ Daha açık bir ifadeyle insanın, sahip olduğu tüm “insani” özellikleridir. Aslında Heidegger'in Varlık ve Zaman eserinde Dasein'ı anlatma çabası, insanları "insan olma”ya çağırma gayretinden köklenir. Heidegger bu yolda varolmanın temel ereklerini betimleyerek ilerler. Bunlar, "dünya-içinde-varlık", "kayg1-duyan-varlık” ve “ölüme-doğru-varlık” tır.

Heidegger'in özne fenomolojisi olan "dünya-içinde-varlık", Dasein’ın varlık konstitüsyonunu nitelendirmektedir. Dasein olmak için dünya içinde konumlanmak, bir bakıma ötekilerle birlikte olmak gerekmektedir. Burada dünya fani, tinsel ya da dünyevi anlama değil, varlığın açıklığına delalet etmektedir. Dünya, insanın fırlatılmış özünden çıktığı, özünü sürdürdüğü alandır. İnsanın özünü dünya-içinde-olmakla sürdürmesi, metafiziksel olarak insanın bu dünyaya mı yoksa öbür dünyaya $\mathrm{ml}$ ait olduğu yönünde bir karar içermektedir. ${ }^{16}$ Öte yandan Dasein’ın dünyadalığı, dış dünyayla kendi varlığı arasında ilişki kurmasına bağlıdır. ${ }^{17}$ Dünyada-olmak, insansal bir varoluşun kökeninde yatmaktadır. İnsan temelde özgür, aşkın ve tamamlanmamıştır. Kendini tanıması, sorgulaması ve varolması Dasein’ın en büyük olanağıdır. ${ }^{18}$

Bahsedildiği üzere Heidegger’in Dasein’ı öz olarak başkalarıyla-birlikte-olmaktır. Eksistensiyal-ontolojik bir anlama sahip olan bu ifade, kendiliğin olgusal olarak tek başına bulunamayacağı veya başkalarının da yer aldığı ontik bir gerektirim değildir. Dasein’ın dünya-içinde-varolmasının özünde birlikte-olmayla tesis edildiğini ileri süren önerme bu anlamda olsaydı, birlikte-olma Dasein’n kendinden türeyen ve varlık biçiminden şekillenen bir eksistensiyal belirlenim olmazdı. Daha açık bir ifadeyle Dasein’ın tabiatı başkalarının yer almaları halinde ortaya çıkardı. Oysaki birlikte-olmak, başkasının fiilen mevcut olmadığı durumda da, eksistensiyal olarak belirir. Dolayssiyla birlikte-olmak ve hep-beraber-

${ }^{13}$ Bryan Magee, Büyük Filozoflar Platon'dan Wittgenstein'a Batı Felsefesi, çev., Ahmet Cevizci, İstanbul: Paradigma Yayınları, 2001, s.275-276.

${ }^{14}$ Heidegger, Varlik ve Zaman, s.44.

${ }^{15}$ Abdulkadir Çüçen, Heidegger'de Varlık ve Zaman, Bursa: Asa Kitabevi, 2003, s.58.

${ }^{16}$ Martin Heidegger, Hümanizm Üzerine, çev., Yusuf Örnek, Ankara: Türkiye Felsefe Kurumu, 2013, s.42.

${ }^{17}$ Rüdiger Safranski, Bir Alman Üstat: Heidegger, çev., Ali Nalbant, İstanbul: Kabalcı Yayınevi, 2008, s.234.

${ }^{18}$ Frederic De Towarnicki, Martin Heidegger Anılar ve Günlükler, çev., Zeynep Durukal, İstanbul: Yapı Kredi Yayınları, 2002, s.58-59. 
olmaklığın olgusallığı öznelerin bir arada olması üzerine temellenmemiştir. Dasein yalnız olduğu zamanlarda bile birlikte-olma halindedir. ${ }^{19}$ Dasein dünyadalığın bütünlüğü olarak öngörülse de kendi varlığının anlamını dünyaiçindeki-şeylerden almamaktadır. ${ }^{20}$

Daha önce de bahsedildiği üzere Homemade kısa film seçkisinin tamamı karantinada çekilmiştir. Hemen her filmin hikâyesi, yönetmenin kendi karantina alanının içinde, küçük bir mekânda şekillenmiştir. Keza Dasein’ın bulunduğu dar alan ya da kendi başına olması içinde-var-olmaklığına ve Dasein olmasına engel teşkil etmediği açıklandı. Dasein’n var-olmaklığı kendi kendinden beslenmesine bağlıdır. Dasein'lar izole hayatlarının içinde bile birlikte-vardır. Başka bir ifadeyle Dasein, tek başına olduğu zaman bile başka Dasein'larla birlikte olarak herkesin içinde kendiliğini bulur. Nitekim on yedi kısa film, aslında benzer duygulardan türeyen hikâyeleri tesis ederek, Dasein'ın "herkes"in (Das man) dünyasında kendine yer edinmesini gözler önüne serer. Demek ki Heidegger'in kurduğu Dasein oluş, modern anlamda özne düşüncesine farklı bir yaklaşım getirmiştir.

Dasein’ı "birlikte-varlık" olmasını açığa çıkaran bir yol da "içinde-olmak"tır. Diğer varlıklar kendini fiziksel olarak nesnel görünüşlerle, Dasein ise varlığını diğerleriyle birlikte ortaya koyar. Örneğin masa, sandalyeye fiziksel olarak dokunsa da ontolojik olarak dokunamaz. Dasein’a özgü dokunma, varlıkla karşılaşmayı, ilgi ve kaygı duymayı, birlikte-olmayı ve yan-yana-olmayı gerektirir. Dünya-içinde-varlık olarak Dasein’ın, diğer nesneler ve insanlarla anlamlı ilişkiler kurması varlığının formal ifadesidir. ${ }^{21}$ Dasein'ın sahih olarak kendi olması, "ilgi"yle mümkündür. Bu, başkalarıyla ya da kendiyle ilgilenmek olarak tezahür edebilir. ${ }^{22}$ Homemade'de yer alan kısa filmlerde karantina döneminde ortaya çıkan yeni ilgi alanları Heidegger'in "ilgi” yaklaşımıyla değerlendirilebilir. Bunlardan biri yemek hazırlamayı seremoniye dönüştürmektir. Sözgelimi yönetmen Johnny Ma, kısa film anlatısının merkezine annesinin tarifi olan Çin mantısını yerleştirmiştir. Film, Çin mantısını çocuklarına yedirmesi ve mantı tarifinin ekrana yansımasıyla son bulur. Bir diğer film Unexpected Gift'de aynı zamanda filmin karakteri de olan yönetmen Gurinder Chadha, karantina zamanlarında ailesiyle yeni deneyimler yaşamanın keyfini çıkardığını ifade etmektedir. Bu deneyimlerden biri çocuklarının deyişiyle "anneleri işe giderken yiyemedikleri harika yemekler" pişirmesidir. Chadha en fazla geleneksel Hint yemekleri pişirmektedir.

Anlaşıldığı üzere söz konusu film koleksiyonunda yer alan birçok karakter Dasein olma belirtileri göstermektedir. Homemade, açılışını ve kapanışını pandemi nedeniyle herkesin eve kapandığı günlerde, Drone kameralarla şehri kuşbakışı izleyen filmlerle yapar. Ladj Ly’nin yönetmenliğini yaptığı antoloji serisinin ilk filminin başkarakteri Buzz, karantina sürecini sosyal medya etkileşimlerinde

\footnotetext{
${ }^{19}$ Heidegger, Varlik ve Zaman, s.126-127.

${ }^{20}$ Mark Blitz, Heidegger's 'Being and Time', and Possibility of Political Philosophy, Ithaca: Cornell University Press, 1981, s.118-119.

${ }^{21}$ Çüçen, Heidegger'de Varlık, s.60-61.

${ }^{22}$ Kaan H. Ökten, "Heidegger'in Varlık ve Zaman'daki Ölüm Çözümlemesi”, Cogito (Ölüm: Bir Topografya Sayıs1), 40, (2004), s.152.
} 
bulunarak, ödevlerini yaparak ve Drone kamerası vasıtasıyla Montfermeil sokaklarında dolaşarak geçirir. Karantinada olma duygusundan sıyrıldığı bu zamanlarda başkalarıyla beraber Dasein olur. Buzz’n Drone kamerası, dünyayla ilişki kurma hevesidir. Seçkinin sonuncu filmi Ride It Out'ta ise yönetmen Ana Lily Amirpour, dış sesin okuduğu metin eşliğinde Los Angeles sokaklarında bisikletiyle dolaşmaktadır. Şehrin karantinada olması nedeniyle sokaklar bomboştur. Sokakların sessizliğini huzurlu bulduğunu söyleyen yönetmen, evde kaldığı süreçte insanlığın geçirdiği dönüşüme vurgu yapar. Koronavirüs'ün insanları eve kapadığı dönemde Amirpour'un bakış açısı değişmiştir. Metinde yer alan karınca analojisi Amirpour'un karantinadaki varoluş keşfini açı̆̆a çıkarmaktadır. Amirpour'un sözleriyle:

“[...] Bisikletli olmak, bisiklet olmaktan farklıdır. Bakış açısı bir şeye karşı tutum veya yöntem bulmaktır. Karınca çaresiz veya değersiz hissetmez, taki bir gün karınca olduğunun anlayana kadar. Dünya ise karıncanın sandığından çok daha büyüktür. Karınca dünyanın ne kadar büyük ve tehlikeli olduğunu bilseydi, karınca için zor olurdu. Karınca olumsuz düşüncelere odaklanmaz. Sadece şuna odaklanır: çok ağır bir yük taşıyan çok küçük bir varlık olduğuna. Karınca gibi biz de bir koloni arzularız. Yapı, iş ve rutinin rahatlığı. Gerçi bazen korkudur bu. Size bakış açısı gerektiren. Acımızı hafifletmek isteriz, medeniyeti ayakta tutan budur. Bunun mimari budur. Korku ayakta tutar. Korkarız çünkü hayatta kalmak korkutucudur $[\ldots] "$

Heidegger'e göre varoluşsal bir etkinlik olarak bir durumu anlamak ve kavramak, o durumu yönetmeye muktedir olmak demektir. Dasein’ın kendi varlığının olanaklarını görmesi de bu şarta bağlıdır. ${ }^{23} \mathrm{Bu}$ doğrultuda Amirpour'un, Heidegger'in kavrayışıyla uyumlu bir Dasein olarak pandemi sürecini yorumladığını söylemek olanaklıdır.

Öte yandan Amirpour, pandeminin beslediği "korku" haletiruhiyesinin altını çizmiştir. Heidegger bu kavramı Dasein olmakla ilişkilendirmiştir. Walter Biemel, Martin Heidegger: An Ilustrated Study by Walter Biemel (1976) adlı çalışmasında Heidegger'in Varlik ve Zaman eserinde Dasein'ın bulunuşunu "korku" ve "kaygı" olarak iki temel duruma bağladığını belirtir. ${ }^{24}$ Heidegger, Soren Kierkegaard’ın etkisiyle kaygı ve korku arasında bir ayrım yaparak, Dasein’n ontolojik varlığını kaygıyla ilişkilendirmiştir. ${ }^{25}$ Heidegger'de korku bir durumdur. Korku, bir şeylerden korkmak olarak dünya-içinde-varolanı tehditkar biçimde, içinde-varolmaklığı ise tehdit edilmişlik içinde açığa çıkarmaktadır. Korkulan şey, dünyaiçinde karşılaşılan varlığı mevcut olan ya da birlikte Dasein olandır. Korku, bulunuşun bir biçimidir. Bulunuş içindeki dünya-içinde-varlığa bir imkan olarak açığa çıkan korkma, dünyayı açımlama özelliğine sahiptir. Daha kesin bir ifadeyle korku her zaman Dasein'ın içindeki varlığı dışa vurmaktadır. ${ }^{26}$ Ayrıca kaygının

\footnotetext{
${ }^{23}$ Çüçen, Heidegger'de Varlık, s.73.

${ }^{24}$ Walter Biemel, Martin Heidegger: An Illustrated Study by Walter Biemel, çev., Javara Lal Metha, New York:

Harcount Brace Jovanvich, 1976, s.48.

${ }^{25}$ Çüçen, Heidegger'de Varlık, s.72.

${ }^{26}$ Heidegger, Varlik ve Zaman, s.148-149.
} 
nesnesinin belirsiz olması, belirsiz bir ruh halinin müsebbibidir. Söz konusu süreçte Dasein diğer varlıklardan ayrılarak kendine döner. ${ }^{27}$ Çünkü korku, hiçi açığa çıkarır. Bütününde varolanı yolundan ettiği için Dasein'da bir sarsıntı oluşturur. Fakat Dasein olmak için sürekli korkuya ihtiyaç yoktur. ${ }^{28}$ Bireylerin pandemi sürecinde yaşadıkları korku, bulunuşun-bir-hali olarak vardır ve Dasein olmanın yolunu açar.

Casino isimli kısa filmde yönetmen Sebastian Schipper, karantina günlerinin rutin gündelik işlerini yaparken kendi versiyonlarıyla arkadaş olduğunu düşünmeye başlar. Elini yüzünü yıkarken, tıraş olurken, saçlarını keserken, yemek yerken ya da gitar çalarken halüsinatif biçimde her bir işi farklı kişi yapıyormuş gibi düşünür. Evdeki tüm sesler ve görüntüler kendisine aittir aslında. Yemek, bilgisayar, tıraş makinesi ve gitar sesi olarak birden fazla kişiden geldiğini düşündüğü ses, kendi sesidir. Schipper’ın varoluşsal birlik hissetmek üzere seçtiği bu yol, başkalarıyla-birlikte-olma ihtiyacını karşıladığı kökensel bir duyumdur. Nitekim Heidegger, "birlikte" dendiğinde Dasein’sal bir niteliğin anlaşılması gerektiğini vurgular. Bu birliktelik hem kategorik olarak hem de eksistensiyal olarak anlaşılmalıdır. Dünya-içinde-varoluş birlikteselliği zeminindeki dünya, başkalarıyla paylaşılan dünyadır. İçinde-var-olmak demek, başkalarıyla-birlikteolma fenomenidir. Dünya-içindeki-varlık olmak, birlikte-Dasein’n özüdür. Başka bir deyişle Dasein’ın dünyası birlikte-dünyadır. ${ }^{29}$ Michael Inwood'un açıklayışıyla buradaki birliktelik yalnızca fiziksel birliktelikle sağlanmaz. Uzaklık, birlikteDasein’n bir modu olarak kabul edilir "çünkü birlikte-olma olarak Dasein, başkalarının Daseinı’ının kendi dünyalarında kendileriyle karşılaşmalarına izin verir." ${ }^{30}$ Buradaki birliktelik Dasein’ın tek başına varolmasının mümkün olmayacağından çok daha öte bir anlama sahiptir. Nitekim Schipper'ın yalnızlığından türettiği birlikte-olma hali, dünya-içinde-olmaklığa erişmesine yardımcı olur. Schipper, kendi kendiyle sohbet ettiği ve poker oynadığ 1 zamanlarda Dasein’n birlikte-dünya için çaresiz kaldığında sınırlarını nasıl zorlayabileceğini gösterir. Bilhassa "Something wrong" isimli şarkıyı söylediği sahnelerde birlikteliğe gönderme yapan kendi bulduğu halüsinatif çözümü parodileştiğini söylemek olanaklıdır.

Heidegger'e göre dünyada-olma, insanın çevresindeki nesnelerle ve ait olduğu toplumun fertleriyle ilişki içinde bulunmasıyla belirlenir. Bu doğrultuda Dasein’ı belirleyenler olgusallık, kişinin varlı̆̆ının potansiyelini kavraması ve meşguliyetleri içinde kendini unutarak sahici varoluşundan uzaklaşmasıdır. ${ }^{31}$ Karantina günlüklerine odaklanan kısa film serisinde bir çok yönetmen, ev içinde gerçekleştirilen gündelik işleri Dasein’ korumak üzere işlevselleştirir. Bu yolla, bir anda değişen dünyalarını yeniden kurarak varoluşlarını korumaya çalışırlar.

Dasein’n dünya-içinde-olmaklığı her kısa filmde farklı şekilde tezahür etmiştir. Penelope adlı kısa film, karantinaya yönelik gerçekçi bir yaklaşımla

\footnotetext{
${ }^{27}$ Çüçen, Heidegger'de Varlık, s.72.

${ }^{28}$ Martin Heidegger, Metafizik Nedir? çev., Yusuf Örnek, Ankara: Türkiye Felsefe Kurumu, 2009, s.35-38.

${ }^{29}$ Heidegger, Varlik ve Zaman, s. 124.

${ }^{30}$ Michael Inwood, A Heidegger Dictionary, Oxford: Blackwell Publishers, 1999, s.31-32.

${ }^{31}$ Ahmet Cevizci, Paradigma Felsefe Sözlüğ̈̈, İstanbul: Paradigma Yayınları, 1999, s.199.
} 
oluşturulmuştur. Şehirden uzak bir evde izole olan Peter Sarsgaard'ın oynadığ 1 isimsiz başkarakter, yarım milyar insanı yok eden ve dünyanın çekim kuvvetini değiştiren bir pandemiden korunmaktadır. Sarsgaard'ın hayatla kurduğu bağ, Dasein olmasının temel belirtilerini içermektedir. İzolasyonla gelen yalnızlığını radyodan gelen haberlerle, izlemekten zevk aldığı bir filmle ya da her gün kullandığ 1 ekmek kızartma makinesiyle bertaraf etmeye çalışır. Heideggere göre Dasein'ın dünya-içinde-varolmaklığı, var-olmanın belirli tarzları içinde parçalanmıştır. Heidegger için var-olmak, bir şeyle uğraşmak, bir şeyi üretmek ya da işlemek, bir şeyi kullanmak, bir şeyi kaybetmek, yeni girişimlerde bulunmak, bilgilenmek, araştırmak, gözlemlemek ya da tartışmaktır. O halde, içinde-varolmanın varlık biçiminin ilgilenme olduğu söylenebilir. ${ }^{32}$

Söz konusu varlık konstitüsyonunun açığa çıktığı bir film de yönetmen Johnny Ma’nın isimsiz filmidir. Belgesel niteliğindeki filminde Johnny Ma, ailesiyle Meksika'da yaşadığı izolasyon sürecinden kesitler sunmaktadır. Yönetmen kısa filmi, annesinin hiç bir zaman okuyamayacağını -filmin sonunda Netflix kullanmadığından dolayı izlemeyeceğini söylüyor- düşündüğü mektup olarak kurgulanmıştır. Zira Dasein’ın ölümlü olma durumu yönetmene sorumluluk yüklemektedir. Ma, mektubunda daha önce annesiyle konuşamadığı, ötelediği duygularını itiraf eder. Film boyunca Johnny Ma ve ailesinin karantina sürecinde yaptığı gündelik işler gösterilir. Ma, annesinin yaptığı Çin mantısını çocuklarına hazırlar. Yönetmen için mantı, annesiyle mutfakta olduğu mutlu zamanları hatırlatan sembol; Çin'deki ailesi ve Meksika’da seçtiği ailesi arasında kurduğu bağdır. Film, geleneksel Çin mantısı tarifiyle sona erer. Ma’nın anılarını günümüze taşıması, karantinada daha fazla vakit geçirdiği ailesiyle bağ kurmasına yardımcı olacaktır. Bir bakıma bu bağ, Dasein’n yeniden canlanmasını sağlayacak varlık anlayışının ufku olarak yorumlanabilir.

\section{Kaygı Duyan Varlık Olarak Dasein}

İşte sonu Heidegger'in varlık görüşü "kaygı" (sorge), "korku” (furcht, fürchten), "endişe" (angst, anxiety) ve iç sıkıntısı gibi haletiruhiyeleri temel almaktadır. Varoluşçu felsefede kaygı, dünyanın anlamsızlı̆̆ının, kaotik yapısının, düzen ve amaçtan yoksun oluşunun farkına varılmasıyla ortaya çıkan duygudur. Heidegger, felsefesinde kaygıya daha fazla önem atfederek, kaygıyı Dasein'ın potansiyelini kullanmasında itici güç olarak konumlandırır. Dasein için kaygı, onu dünyadaki sindirilmişlik duygusundan kurtarmak üzere kesilmiş bir bilettir. Kaygının sağladığı bireyselleştirme, Dasein'ı kendine getirerek kendi varlık imkanlarını keşfetmesine yardımcı olur. Yapmacıklığın ve sahiciliğin farkına varan insan, vicdanının sesini dinler ve Dasein'ı kendi olmaya davet eder. ${ }^{33}$ Nitekim kişisel varoluş, kişinin kendini tasarlamasıdır. İnsanın ucu açık bir geleceğinin olması, biçimlenmemiş ve tamamlanmamış olduğunu gösterir. Bu özelliğine bağlı olarak Dasein yapısal olarak kendinden ileridedir. Bu noktada ortaya çıkan geleceğe ve ne olacağına dair endişesi, kaygı terimi ile ifade edilmektedir. ${ }^{34}$ Kaygı, insanın

\footnotetext{
${ }^{32}$ Heidegger, Varlik ve Zaman, s.58-59.

${ }^{33}$ Cevizci, Paradigma Felsefe, s.502.

${ }^{34}$ Harol John Blackham, Altı Varoluşçu Düşünür Kierkegaard Nietzsche Jaspers Marcel Heidegger Sartre, çev., Ekim Ușşaklı, Ankara: Dost Kitabevi, 2005, s.100.
} 
yeniden özüne kavuşturan biricik yoldur. İnsanın "insanca” olmasının temel ereklerindendir. ${ }^{35}$ Ayrıca insanın özü itibarıyla fani oluşu, kaygılı halinin müsebbibidir.

Homemade antoloji serisinde yer alan kısa filmlerin büyük kısmı pandemi ile ilgili bireysel ve toplumsal kaygılara odaklanmıştır. Ferosa isimli kısa film, karantina sürecinde evde zaman geçiren ergenlik çağındaki çocukların kaygılarını konu edinmiştir. Pandemiden sonra toplumsal düzeyde yaşanacak değişimler, ihtimam-göstermelik bir olgu olarak anlatıya yerleştirilmiştir. Bir başka kısa film Espacios'da karantina sürecinde nükseden kaygı, yine çocuklar üzerinden anlatılmıştır. Yönetmen Natalia Beristáin kendi kızını oynattığı filminde, dört-beş yaşlarındaki bir kız çocuğunun karantinadaki gündelik yaşamını anlatmıştır. Filmin sonunda karantinanın çocukların geleceğiyle ilgili daha çok düşünmeye vesile olduğu fikrinin altı çizilmiştir. Last Message adlı filmde salgın sürecindeki bireyin karamsar dünyası yansıtılmıştır. Özellikle öznel kamera açıları aracılığıyla başkarakterin kaygılı ruh hali vurgulanmıştır. Bilhassa "metanet" sözcügüüün sıklıkla tekrarlaması kaygı halinin idrakini desteklemektedir. "Böyle devam ederse yarın neler olur?" sözleriyle başlayan film, "Her sonun bir başı vardır. Bu daha hikâyenin başlangıcı [...] Hafıza, bilgi, abeslik, sınır yok” sözleriyle devam eder. Karamsarlığa kapılmış Dasein, kaygılarından kurtularak kendi varlığını gerçekleştirmek istemektedir. Bunu yapmasının yolu da yine kendi deyişiyle "sanat ve metanet”tir. Paul Hühnerfeld, Dasein'ın yaptığı, ettiği, düşündüğ̈̈ her şeyin dünyada-olma durumunun içinden doğduğunu ifade eder. Dolayısıyla Dasein, kayg1dan sıyrılamaz. İnsanı metafiziksel anlamda yalıtılmış bir mekânda, her şeyden sıyrılmış olarak görmek mümkün değildir. Çünkü insan nesnelerle, renklerle ve eşyalarla yaşamaktadır. İşte bu yüzden Dasein yalıtık bir özne olamaz ve yaşamının her alanında bir tavır almak zorunda kalır. ${ }^{36}$ Söz konusu bu tavır Last Message'da, sanata sığınma isteği içinde meydana çıkar.

Pandemi sürecinin neden olduğu olumsuz ruh halini sanatla aşmayı yeğleyen yaklaşıma sahip diğer kısa film de Ride It Out'dır. Yönetmen Amirpour'un, bisiklet gezintisine eşlik eden dış ses sanatla, bilhassa pandemi sürecinde sanatın değişen çehresiyle ilgili önemli saptamalarda bulunur:

"Evde kalmak zorunda olduğumuzdan hepimizin bakış açısı değişti. Sanat mesela, tanıdık bir şeye yeni bir bakış açısıyla yaklaşmaktan ibarettir. Bir sanatçının işi yerleşik tanımı parçalayıp baştan yaratmaktır [...] Tanımını parçalamak ve yeniden tanımlamak. Hayatlarımız tanıdıktı ve şimdi yeniden inşa edilmeleri gerekiyor. İşte bu yüzden sanat, hayatta kalmanın bir yoludur."

İlk olarak Amirpour'un bisiklet sürerken özgürleştiğini hissettiğini söylemesi, Heidegger'ci yaklaşımla varolanı oluruna bırakan Dasein olarak hakikati açı̆a çıkarmaktır. Zira hakikat, varolanın mevcudiyetinin ifşa edilmesidir. ${ }^{37}$ Yönetme-

\footnotetext{
${ }^{35}$ Heidegger, Hümanizm Üzerine, s.11.

${ }^{36}$ Paul Hühnerfeld, Heidegger. Bir Filozof, Bir Alman, çev., Doğan Özlem, Ankara: Gündoğan Yayınları, 1994, s.15.

${ }^{37}$ Martin Heidegger, "Hakikatin Özü Üzerine”, çev., Nejat Aday. Düşünce, Siyaset, Sosyal Bilim Dergisi 36-37
} 
nin bisiklet sürerek özgürleştiğini hissettiği anlarda, yaşadığı süreci anlamlandırmasına yarayan bir farkındalık oluşur. Amirpour'un bu süreçte kamerasını Hollywood'un simgeleşmiş mekânı Sunset Bulvarı'na ve Chinese Theater'a çevirmesi pandeminin sanat alanında yol açtığ değişiklikleri vurgulamaktadır. Antoloji serisinin son filmi olan Ride It Out, bir bakıma yönetmenlerin çoğunun evlerinden çektiği kısa filmlerle, sanat anlayışının değişen çehresini yüzleştirmiştir. Bu yaklaşım aslında Heidegger'in sanat anlayışıyla da örtüşmektedir. Heidegger felsefesine bütüncül bir şekilde yaklaşıldığında, "varlık"ın ve "hakikat"in anlamını sorguladığı söylenebilir. Heidegger, varlığın doğruluğunu -hakikati- sanatta aramıştır. Özellikle şiiri, varlığnı hakikati olarak kavradığını belirtmiştir. ${ }^{38} \mathrm{Hei}$ degger'in vurguladığı gibi "insan, sanatın özüyle ilgili bilgi sağlama amacıyla sanatı deneyimler." Buradaki öz, hakikatin oluşudur. ${ }^{39}$ Sanatın, hakikatin kendini ortaya koyma yollarından biri olması tarihsellik özelliğiyle vuku bulur. Dolayısıyla tarihsel süreç içinde Dasein'ın kendi özünü ortaya koyma biçimlerinden biri de sanattır. Pandemi sürecinde sanat, Dasein'ın diğerleriyle birlik içinde olmasına yarayan, kaygı ve ölüme karşı varlığına hakikat kazandıran bir "görüngü” olarak ortaya çlkar.

Bu noktada Antik Yunan'dan beri kullanılagelen kavram olan aletheia kavramına değinmek gerekir. Antik Yunan'da aletheia gizliliğin ortadan kakması ya da açığa çıkma olarak kullanılmıştır. ${ }^{40}$ Heidegger'de aletheia, gizlilikten türeyen bir anlama sahiptir. Aletheia, varolanı kendi mahfuzluğundan çıkararak keşfedilmeye açık hale getirir. ${ }^{41}$ Heidegger'e göre hakikatin özü mahfuz olduğu için aletheia'ya ulaşmanın tek yolu sorgulamaya devam etmektir. ${ }^{42}$ Varlığı ifşa eden aletheia'nın, hakikati görünür kılan, yeni bir bakış açısıyla bakmaya yarayan bir anlamı vardır. Karantina süreci, Dasein'a dünya-içinde-varlığını yeniden sorgulama sürecine girdiği, kendini anlamaya çalıştığı ve hakikatle yüzleştiği bir deneyim yaşatmıştır. Dasein'ın konumunu belirleyen, bahsedildiği üzere sanatla ya da başka yollarla kendiliğini ve biricikliğini ortaya koymaktır. Rıde It Out'ta sanat hakikat karş1sında bir sığınak olarak kabul edilirken, Algoritmo adlı kısa filmde şarkı söylemek ve dans etmek üzerinden hergünkülügüün içindeki saklı anlam açığa çıkarılır.

Dasein'ın kaygısı sürekli ortaya çıkan ontik niteliklerden, psikolojik ya da fizyolojik kaygılardan öte, varoluşsal bir kaygıdır. Ayrıca gündelik hayatta bu kaygı içinde bulunması herkesin dünyasında olmasından kaynaklanır. Halbuki Dasein'ın varoluşsal kaygısı, sahih olandır ve onun münferitleşmesine yardımcı olmaktadır. ${ }^{43}$ Genç bir kadının insomnia ile mücadelesini gösteren Crickets adlı film bunlardan biridir. Karantina sürecini yalnız geçiren bir genç kadının ruh sağlığı bozulmuştur. Eve sıkışmanın verdiği rahatsızlığa uykusuzluğun da eşlik etmesi, evde sanki başka biri varmışçasına davranmasının müsebbibidir. Uykusuzluk, anksiye-

\footnotetext{
(2004), s.138.

${ }^{38}$ Çüçen, Heidegger'de Varlık, s.146; 159.

${ }^{39}$ Martin Heidegger, Poetry, Language, Thought, çev., Albert Hofstadter, New York: Harper \& Row, 1971, s.71-79.

${ }^{40}$ Barry Allen, Truth in Philosophy, Cambridge: Harvard University Press, 1993, s.87.

${ }^{41}$ Heidegger, Varlik ve Zaman, s.231.

${ }^{42}$ Martin Heidegger, Pathmarks, New York: Cambridge University Press, 1998, s.182.

${ }^{43}$ Heidegger, Varlik ve Zaman, s.211-212.
} 
te ve depresyona ek olarak filme de adını veren cırcır böceklerinin seslerinin genç kadına musallat olması, filmi varoluşsal bir fisıldamaya dönüştürür. $\mathrm{O}$ halde pandemi sürecinde bütün varolanları kuşatan kaygının, psikolojik ve fizyolojik problemlere de yol açtığını belirtmek gerekir.

Heidegger kaygıyı dünya-içinde-varolmanın temel bulunuşu olarak önceler. Bulunuş, "afiyet"i açıklarken, kaygı hali "tekinsizlik"i içinde taşımaktadır. Fırlatılmışlı̆̆ından kaçan Dasein, tekinsizlikle birlikte kendini açığa vurarak dünyaiçinde-varoluşunun hiçliğiyle karşı karşıya kalır. ${ }^{44}$ Bu karşılaşma Dasein'e yuvasızlığını -evinde-yurdunda-bulunmayışını- hatırlatır. Kamusal alanda yuvasızlığının üzerini örten Dasein aslında kendi tekinsizliğinden kaçmaktadır. Ne zamanki kendi tekinsizliğiyle baş başa kalırsa Dasein başka kimseyle karıştırılmayacak kadar kendiyle yüz yüze gelir ve kaygı hali üzerine sirayet eder. Aslında Dasein kendi evindedir ama kaygı ona kendini yuvasız hissettirmektedir. ${ }^{45}$ Karantina sürecinde olmak, varoluş kaygısından, bir nevi tekinsizlikten kaçmayı olanaksız kılarak, evde olmayı kaygıyla yan yana getirmiştir. Kaygıyla birlikte insanın en iyi bildiği yer olan evi, yabancı bir yerde olma hissi uyandırmıştır. Dasein'ın kendini en güvende hissettiği alan olan evi, belirsiz, tekinsiz ve varoluşunu sorguladiğı bir yere dönüşmüştür. George Steiner'ın ifade ettiği üzere ${ }^{46}$ yabancılaşmanın getirdiği yurtsuzluk hissi, Dasein'ın hakikat kavrayışına ilişkin bir yorumunu kaybetmiştir. Dasein'ın yabancılaşmış hali, otantik olmayan bir yaşamda varlığını sürdürdügünü göstermektedir.

Karantinada Dasein'ın varlığına ilişkin bir çok şeyi ifşa eden filmlerden biri müzikal niteliği taşıyan Algoritmo'dur. Amalia Kassai’ni canlandırdığ filmin tek karakteri, şarkı söyleyerek ve dans ederek evde-olmayı ya da eve mahkum olmayı sorgular. Kassai, kendi evinde yabancı gibi hissetmektedir. Bu duyguyu aşabilmek adına daha fazla temizlik yapar, mutfakta oyalanır ve evin çeşitli yerlerinde şarkı söyler. Kassai'nin pandemiyi yorumlama amacıyla yazdığını söylediği sekiz dakika süren şarkı, karantina sürecine ve varoluşçu suallere kenetlenir. Filmin en önemli özelliği "pandemiyi dünya meselesi olarak" sanatsal bir dille ifşa etmesidir. Ayrıca pandemiden önceki yaşayışımızı da benzer bir yaklaşımla eleştirir:

“[...] Hastalık ve trajedi dönemi bu kendi bedenlerimizi keşfetmeyi öğrendik,

bilinçli ve hezeyan dolu tecrit, gülünç, sonsuz ve zorunlu

şimdi eski halimiz daha net görüyorum

Eve mahkum olduk [...]

Soyu tükenmiş bir paradigmanın kökten değişimine duyuyoruz hasret

Acaba insan soyu akıllanmış olur mu nihayet? [...]

Köşelerinde pas görüyorum mutfağın ve ruhumun

Kendi yansımama çarpıyorum pencere ve duvarlarımdaki [...]

Bir sürü yeni duygu dehşete düşme ve nöbetler

\footnotetext{
${ }^{44}$ Heidegger, Varlik ve Zaman, s.199.

${ }^{45}$ Heidegger, Varlık ve Zaman, s.292-293.

${ }^{46}$ Georg Steiner, Heidegger, çev., Süleyman Sahra, Ankara: Hece Yayınları, 2003, s.130.
} 
Evcimen judo kafakolları kendine atılan tokatlar [...]

Bir gezegende yaşıyoruz boşlukta süzülüyoruz

İmparatorluklar kurduk ama maymundan ibaretiz

Ölülere borçluyuz baştan aşağı yenilenmeyi

Hep birlikte, ya hep ya hiç cesaret ve ilham

Şimdi değilse ne zaman güzellik ve yaratım? [...]”

Pandemiden dolayı tüm insanlıkla birlikte Kassai’nin de üzerine çöken anksiyete hali, Heideggerci yaklaşımla bir kez daha izah edilebilir. Evinde ama yurtsuz hisseden Kassai, daha önce kafa yormadığı konular üzerinde düşünerek, eski haline yabancılaşmıştır. Sürekli temizlediği, her noktasında gezindiği evi, sıkışıp kaldığı bir uzama dönüşmüştür. Mekânın derinliği arttırıldıkça Kassai’nin varlığını keşfedebilirliğinin arttığı gözlemlenir. Şarkı söylerken kolostrofobi duygusuna işaret eden beden dili hareketleri, Kassai' nin yeni deneyimlediği duyguları ifade etmesine yardımcı olmaktadır. Başkarakterin karantinayı geçirdiği ev, gerek kamera hareketleriyle gerekse şarkıya eşlik eden dans figürleriyle Dasein'ın kendinden kaçamadığı ve kendiyle yüzleşmek zorunda kaldığı bir alan olarak tasvir edilmiştir. Heidegger, Dasein'ın içinde-var-olmaklığın eksistensiyal anlamı olan içindeolmaklığı bir yerlerde ikamet etmek olarak belirlemiştir. İçinde-var-olmaklık, somut olarak ele alınırsa herkesin gündelik kamusallığı içinde aşina olduğu şeylerdir. Dasein'ın gündelik yaşamındaki kamusallığı, yatıştırılmış kendine güven duymayı ve hergünkülüğün ortalamasını barındırmaktadır. Oysaki kaygı, Dasein'ı dünyaya aşinalığından kopararak münferitleştirir. Dasein münferitleşme halini içinde-var-olmak olarak gerçekleştirir. Karantina süreciyle değerlendirildiğinde evde kalma hali Dasein'ı içinde-var-olmaklıktan, içinde-kimseninolmamaklığının tabi olduğu eksistensiyal "hal"e dönüştürmüştür. ${ }^{47}$ Sözgelimi Dasein için evde geçirdiği karantina süreci, evde-olmamaklığa dönüşerek insanın varoluşuna dair bir çok fenomeni yeniden meydana getirmiştir.

\section{Dasein’ın Otantik-Varlık-Olanaklılığı Olarak Ölüm}

Uygarlığın ilk Heidegger, Dasein'ın noksanlığıyla beraber varolduğunu ve kendi "tamlığına” erişemeyeceğini ileri sürer. Dasein için ölüm sahih bir varlıktır ve dünya-içinde-varolmanın sonu ölümdür. Varlığın imkanınına ya da varoluşuna ait bu son, Dasein'ın olası bütünlüğünü aşındıran ve belirleyen biricik etkendir. Dasein'sal yaklaşımla ölüm, yalnızca varoluşsal bir ölüme-doğru-varlık içinde gerçekleşebilir. ${ }^{48}$ Dasein'ın ölümle ilişkisi, ölümün iki temel niteliği olan kesin ve belirsiz olmasıyla değerlendirildiğinde anlaşılır. Bu nitelikler Dasein'ın imkan alanını da tayin eder. Dasein'ın ölecek olmasındaki kesinlik, tüm yorumsamalardan sıyrılan en hakiki ifadedir. Burada ölümlülük, ölüme yol açacak bir vesileyle hastalık vb.- gerçekleşmeyen, bizatihi varoluşla ilişkili olarak kavranmalıdır. ${ }^{49} \mathrm{O}$ halde Dasein'ın ölümü katıksız şekilde kabul ederek (amor fati) hakiki varoluşu-

\footnotetext{
${ }^{47}$ Heidegger, Varlik ve Zaman, s.199.

${ }^{48}$ Heidegger, Varlik ve Zaman, s.248.

${ }^{49}$ Martin Heidegger, History of the Concept of Time: Prolegomena, çev., Theodore Kisiel, Bloomington: Indiana University Press, 1985, s.317.
} 
nu ortaya çıkaracağ ${ }^{50}$, ölüme-doğru-varlık olarak belirsizliği aşmaya çalışacağ 1 beklenebilir.

Anlaşılan o ki Dasein için ölüm, varlığın-tamlığına-doğru olanağı ve dünyaiçinde-varolmanın "hitamı"dır. Mutlak olanaksızlığının olanağı olarak ölüm, Dasein'ın kaygı ve korkuya ilişkin ruh-durumunu ${ }^{51}$ ortaya koymaktadır. Ölümle yüzleşme kaygısı Dasein'ın varlığı-kendi-olanaklılığı içinde dünya-içinde-varlık olmasını sağlar. Ölümün varoluşsal olanaklılığı kaygıda temellenir ve Dasein'ın ölümle arasına kaygı girer. Çoğu zaman Dasein kesinliğin zamanının belli olmayışından beslenen bir kaçışa doğru yönelir. Diğer yandan ölümün gelmekte oluşu Dasein'ın kendi olanaklarını görmesine imkan sağlar. Ölüm beklentisi, otantik olanakların genişlemesine ve varlığını anlamlandırmasına yardımcı olur. ${ }^{52} \mathrm{O}$ halde Heidegger'de ölüm, hakikati açığa çıkartması itibariyle Dasein'ın varlığına özü gereği vekalet eder. Hatta ölümün Dasein'ın kendisi için olduğu bile ilam edilebilir. ${ }^{53}$ Pandemi, ölüme-doğru-varlık olduğunu hatırlattı̆ğ Dasein'da varlık olanaklarını sorgulama içtepisi oluşturur.

Homemade'de ölümü kabulleniş, ölüme yönelik varlığ yeniden tasarlama ve varlığının sınırlarını aşmaya çalışma eğilimi olarak çeşitli filmlerde ortaya çıkar. Ölüm-için-varlık düşüncesi Dasein'ı yeni bir hayata doğru iterek Dasein'ın dünya-içinde-varolmaklığına farklı bir anlayış eklemler. Sözgelimi Voyage Au Vout De La Nuit filmi İngiltere Kraliçesi Elizabeth ve Papa Francis'in küçük figürlerini kullanarak iki önemli liderin sosyal mesafeli yaşamlarını ironik bir dille hikâyeleştirir. Kraliçe Elizabeth’in Papa Francis'le olan diyalogları çoğu zaman çocuksudur ve ilanıaşk içerir. İnsanlık karantinayla yeni tanışmıştır fakat Kraliçe Elizabeth bu duruma aşinadır. "Zaten 94 yıldır karantinadayım” sözleriyle izole yaşamının ve yalnızlığının altını çizer. Kraliçe Elizabeth için karantina yaşam becerilerini kısıtlar kısıtlamasına ama onu Dasein olmanın imkanlarından koparmaz. Nitekim ölüm kaygısı, Dasein'ı yalnızlaştırırken, kendi varlık imkanını idrak etmesini ve diğer Dasein'larla bir aradalık içinde olmasını mümkün kılmaktadır. ${ }^{54}$ Dahası münferitleşme Dasein'ı kendi düşkünlüğünden çıkarmaya aracılık eder. ${ }^{55}$ İngiltere Kraliçesi'nin “Kısıtlama ruha özgü bir durumdur” ifadesi Dasein’ın özünün gizli kalan karakterizasyonunu açığa çıkardığına işaret etmektedir. Zira özgür olmak, varolanı oluruna bırakmaktır. Burada özgürlük hakikatin özü olması itibarıyla, teslim-oluşla vücut bulur. Heidegger burada özgürlügün ne olmadığını da belirtir. Özgürlük, ara sıra ortaya çıan keyfi bir şey ya da istenilen ve zorunlu olunan şey değildir. Dolayısıyla Kraliçe Elizabeth'in vurguladığı üzere kısıtlamalar Dasein'ın özgürlüğüne engel teşkil etmez, çünkü özgürlük yine Heidegger'in deyişiyle ${ }^{56}$ "Da-sein'da mahfuzdur."

\footnotetext{
${ }^{50}$ Blackham, Altı Varoluşçu, s.101.

${ }^{51}$ Korku, unutma, bekleme, şimdide bekleme haletiruhiyeleri olarak ortaya çıkarken; kaygı, alıkoyma, tahmin ve olmuşluk olarak kendini göstermektedir. Michael Gelven, Acommentary on Heidegger's Being and Time, Dekalb, IL: Nethern Illinois University Press, 1989, s.189.

${ }^{52}$ Çüçen, Heidegger'de Varlık, s.87-88.

${ }^{53}$ Otto Pöggeler, Martin Heidegger's Path of Thinking, çev., Daniel Magurshak ve Sigmund J. Barber, Atlantic Highlands: Humanities Press International, 1987, s.211.

${ }^{54}$ Ökten, Heidegger'in Varlik, s.153.

${ }^{55}$ Heidegger, Varlik ve Zaman, s.201.

${ }^{56}$ Heidegger, "Hakikatin Özü”, s.135-137.
} 
Dasein'ın, ölüme-doğru-varlık olması bilinci, diğerleriyle birlikte olma çabasına koşut biçimde gelişir. Dasein, diğerleriyle olan etkileşim şeklinde yeniden yapılanmaya yönelir. Daha önce bahsedilen korku, kaygı, belirsizlik ve tekinsizlik haletiruhiyesine bir de ölüme-doğru-varlık eklendiğinde, başkalarıyla-birlikteolmak için teknolojiye daha fazla başvurur. Teknoloji en kestirme yoldan, Dasein'ı evin sınırlarından çıkararak, ona sınırsız bir mekânda olma deneyimi yaşatmaktadır. Dasein'ın varlığı bir mekâna sıkıştırıldığında, dünyayla varlığının kapsamı azalır. Dasein'ın evinin sınırları içinde yer alan nesneler -kitabı, kanepesi, yatağ 1 vb.- evin sınırları içinde kalırken, teknolojik aletler sınırsız iletişim sağlayarak varlığın kapsamını arttırır. Homemade kısa film serisinde karantina sürecinde teknolojinin imkanlarıyla sağlanan iletişimi tasvir eden hikâyeler bulunmaktadır. Bunlardan biri olan Last Call, huzurevinde yaşayan yaşlı bir adamın Zoom uygulamasıyla eski sevgililerini aramasına odaklanmaktadır. Zoom ortamındaki sohbet, mizahi bir dille aktarılmıştır. Pandemi sürecinde tüm dünyada etkinliği artan dijital mecraların filmde de başrolde olduğu söylenebilir. Yaşlı adam, görevlilerin yardımıyla aradığı eski sevgililerini hiç unutmadığına ikna etmeye çalışır. Fakat çok geçmeden kendini farklı biri gibi gösterme çabasında olduğu anlaşılır. Yaşlı adamın eski sevgililerine fiziksel rahatsızlıklarından bahsetmesinde, ölüme yakınlıkla ilgili bir kaygı duyması söz konusudur. Varlığının kapsamını genişletmesine zoom vekalet etmektedir. Yeni medya araçlarını ön plana çıaran diğer kısa film Couple Splits Up While in Lockdown LOL'dur. Film, karantina sürecinde ilişkilerinde sorunlar yaşayan bir çiftin odalarını ayırarak mesaj yoluyla iletişim kurmalarını anlatmaktadır. Film, bir bakıma modern anlamda ilanıaşka ayna tutmaktadır.

Heidegger'e göre Dasein varolduğu sürece kendi varolma imkanlarını gerçekleştirmeye çabalar. Önünde gerçekleştirmesi gereken bir şey kalmadığını düşündügünde Dasein kendini önceleyerek, gerçekleştirmek üzere yeni şeyler üretir. Çünkü Dasein en yoğun "ümitsizlik" durumunda bile varolma imkanlarının tükenmediğini bilir. Dasein’ın temel konsitüsyonu özünde “tamamlanmamışlık”la biçimlenir. Dolayısıyla Dasein varolmanın imkanlarına hep açıktır. ${ }^{57}$ Ride It Out filminde Amirpour, "insan, ancak kendi ölümüne doğru ilerlediğinin farkına vardığında tam olgunluğa ulaşır” sözleriyle Dasein'ın varlık minvaline nasıl ulaştığını hatırlatır. Heidegger'e göre Dasein bir bütün olmasına rağmen henüz tam olarak gerçekleşmemiştir. Bu noktada Heidegger "ham meyve" örneğine başvurur. Ham meyve henüz olgunlaşmamıştır, demek ki kendini tam olarak gerçekleştirmemiştir. Fakat meyvenin olgunlaşması için kendi özünde bulunmayan şeyler ilave edilmez. Hamlıktaki henüz-olmamışlık, meyvenin eklemlenmesiyle mevcutolan harici bir ötekiliğe işaret etmez. Meyvenin hamlığı, özgül bir varlık minvali, bir bakıma temellendirici öğesidir. İşte Dasein'ın varlığı da bu şekilde işler, yani Dasein kendi henüz-olmamışlı̆̆ındadır. ${ }^{58}$

“Ölüm” hali Dasein'ın en otantik varoluş tarzıdır. Heiddegger'in Varlık ve Zaman eserini inceleyen Mark Blitz, ölümün yalın anlamıyla kavranmasının otantiklik

${ }^{57}$ Ökten, Heidegger'in Varlik, s.127.

${ }^{58}$ Heidegger, Varlik ve Zaman, s.259. 
kavramını da açıklayacağını ifade eder. ${ }^{59}$ Ölüm, ilk bakışta Dasein'ın varlığının yok oluşu gibi gözükse de otantik Dasein'ın varoluşu olanaklı değildir. Ölümle yüzleşen Dasein kararlı bir şekilde varolarak otantik olabilir. Çünkü ölüm kaygısı kendi varlığının hakikatini ve kim olduğunu anlamasını sağlayarak onu başkalarından ayırmaktadır. Otantik Dasein, varlığının hakikatini geçiciliği ve zamansallığ 1 içinde kavrayarak başkalarından ayırır. ${ }^{60}$ İnsanın edimlerinin farkında olması, hiçliğini görmesine yardımcı olur. Aslında tüm yaşamının tesis edicisi "hiçlik"tir. ${ }^{61}$

Homemade'de yer alan bir çok kısa filmde ölüm hakikatiyle yüzleşen Dasein'ın, varlığının manasını aramaya yöneldiğini söylemek olanaklıdır. Çünkü Dasein'ın hayata mana vermesi, otantik olmasının en önemli yoludur. Koronavirüs, varolan bir gerçeği -ölümü- yeniden hatırlatarak, Dasein'ın hayata bakışını yeniden düzenler. Sözgelimi Voyage Au Vout De La Nuit filminde Elizabeth ve Papa Francis, otantikliğin "kendiyle olma" haliyle yıllardır hemhallikleri üzerine sohbet ederler. Zira kişinin kendinin yani benliğinin farkına varması, otantik olmasının biricik delilidir. Algoritmo'da ölümle yüzleşme ve kaygı hali Kassai'nin insanın varoluşunu anlamasına, başka bir deyişle otantik olmasına olumlu katkı sağlayan mahiyettedir. Kısa film antolojisinin son filmi Ride It Out filminde kendi benliğine odaklanan Amirpour, evrende meydana gelen değişmeleri kendinden yola çıkarak anlamlandırır. Zor zamanlar geçiren insan için huzura erişmek için otantik olmak iyi bir yoldur. Heidegger'in belirttiği üzere Dasein başkalarıyla birlikte varolsa da otantik olması, kendinde varlık olmasina delalet eder.

\section{Sonuç ve Değerlendirme}

$\mathrm{Bu}$ çalışmada koronavirüs pandemisi, Netflix orijinal içeriği Homemade (2020) isimli kısa film antolojisi üzerinden Heidegger'in ontolojik varoluşçu kavramlarıyla değerlendirilmiştir. Karantina koşullarında çekilen on yedi kısa filmin kişisel telefonlar aracılığıyla çekilmesi, yönetmenlerin evrensel bir krizi kişisel bir dille aktarmalarına yardımcı olmuştur. İnsan, günlük rutininde kendi varoluşunu sorgulamayı çoğu zaman düşünmezken, karantina süreci Dasein'ın "bu dünyada varolan insan olmaklığı"nı açığa çıkarmıştır. Koronavirüs pandemisi bir yandan korku, kaygı ve anksiyeteyi beslerken, diğer yandan insana, ölümün yakınlığını idrak ettirmiştir. Bu haletiruhiyeler, varlık idesini yeniden sorgulamaya yol açmıştır. Dasein'ın tüm dünyadan ve gündelik meşgalelerinden soyutlanması kökensel bir duyuma ulaşmasına aracılık etmiştir. Bir bakıma karantinanın Dasein'a varlığını anlayacağı bir mühlet verdiği iddia edilebilir. Böylelikle, insanın varoluş sorgulamasında ufku aydınlandıkça dünya ile etkileşimi yeni bir boyut kazanmıştır. Dasein varlıktan neşet ettikçe Heideggerci düşünceye yaklaşmıştır. Karantinanın hissettirdiği yalnızlığı, Heidegger’in deyişiyle dünyada-içinde-varlık ve başkalarıyla-birlikte-varlık olduğunu hatırlayarak aşmaya çalışmıştır.

Heidegger'in “dünya-içinde-olmak”lı̆̆ı, Dasein'ın fırlatıldığı dünyadaki ilgilendiği alanlarla kök salar. Dasein'ın temel varlığı çevresindeki bir takım nesnelere,

\footnotetext{
${ }^{59}$ Blitz, Heidegger's Being, s.111.

${ }^{60}$ Çüçen, Heidegger'de Varlik, s.114, 118.

${ }^{61}$ Marjorie Grene, Heidegger, London: Bowes \& Bowes, 1957, s.48.
} 
zamana, mekâna ve başkalarına bağlıyken, pandemiyle birlikte dünyadakivarlığının kapsamı azalmıştır. Fakat Dasein, dar ve sınırlı dünyasının ötesinde dışardaki varlıkların, Das Man'ın farkındadır. Heidegger'in bu kavramı Homemade'de karantina sürecinde her türlü gündelik rutininden uzaklaşan bireyin toplumla yeniden bağlantı kurmasının bir yolu olarak açığa çıkarılır. Bu doğrultuda çalışmada öncelikle Dasein'ın dünyayla olan ilişkisi, sonrasında ölümlülügü kabul edişi irdelenmiştir. Pandemi, Dasein'a ölüme-doğru-varlık olduğunu hatırlatan bir fenomen olarak değerlendirilmiştir. Ölüm, Dasein'ın olasıllklarının sınırlarını oluşturmaktadır. Dasein ancak varlığını anladığında ve ölüme-doğruvarlık olduğunu kabul ettiğinde dünya ile varlığını yönlendirebilir. O halde denilebilir ki Heidegger'in ontolojisinde kaçınılmaz olan ölüm, kısa film seçkisinde Heideggerci bir tasvir içinde sunulmuştur. Bu doğrultuda kısa film antolojisinin, pandemi öncesinde ölüm üzerinde böylesine kafa yorulmadığının altını çizdiğini ve ölüme-doğru olmanın nasıllığının incelenmesine olanak tanıdığını söylemek mümkündür. Sonuç olarak Homemade'in Heidegger'in felsefesini bir eylem olarak açığa çıkaran anlatı yapısına sahip olduğu bulgulanmıştır. Ayrıca kısa film seçkisi yalnızca Heidegger'i değil birçok varoluşçuyu da aynı çatı altında toplayabilir ve varoluşsal paradigmanın temel çatışmalarını ortaya çıkarabilir. Bu doğrultuda kısa filmlerin Heidegger'in ontolojisi doğrultusunda hala çözülebilecek noktalarının olduğunu belirtmek gerekir.

\section{Kaynakça}

Allen, Barry. Truth in Philosophy. Cambridge: Harvard University Press, 1993.

Biemel, Walter. Martin Heidegger: An Illustrated Study by Walter Biemel. Çev., Javara Lal Metha. New York: Harcount Brace Jovanvich, 1976.

Blackham, Harol John. Altı Varoluşçu Düşünür Kierkegaard Nietzsche Jaspers Marcel Heidegger Sartre. Çev., Ekim Uşşakl1. Ankara: Dost Kitabevi, 2005.

Blitz, Mark. Heidegger's 'Being and Time', and Possibility of Political Philosophy. Ithaca: Cornell University Press, 1981.

Cevizci, Ahmet. Paradigma Felsefe Sözlüğü. İstanbul: Paradigma Yayınları, 1999.

Çüçen, Abdulkadir. Heidegger'de Varlık ve Zaman. Bursa: Asa Kitabevi, 2003.

Falzon, Christopher. Philosophy Goes to the Movies: An Introduction to Philosophy. London \& New York: Routledge, 2002.

Heidegger, Martin. Poetry, Language, Thought. Çev., Albert Hofstadter. New York: Harper \& Row, 1971.

Heidegger, Martin. “The Turning." Çev., Kenneth R. Maly. Research in Phenomenology. 1 (1971): 3-16.

Heidegger, Martin. The Question Corcerning Technology and Other Essays. Çev., William Lovitt. New York \& London: Garland Publishing, 1977.

Heidegger, Martin. History of the Concept of Time: Prolegomena. Çev., Theodore Kisiel. Bloomington: Indiana University Press, 1985.

Heidegger, Martin. Pathmarks. New York: Cambridge University Press, 1998.

Heidegger, Martin. "Hakikatin Özü Üzerine” Çev., Nejat Aday. Düşünce, Siyaset, Sosyal Bilim Dergisi. Sayı 36-37 (2004): 125-148. 
Heidegger, Martin. Varlık ve Zaman. Çev., Kaan H. Ökten. İstanbul: Agora Kitaplığı, 2008.

Heidegger, Martin. Metafizik Nedir? Çev., Yusuf Örnek. Ankara: Türkiye Felsefe Kurumu, 2009.

Heidegger, Martin. Hümanizm Üzerine. Çev., Yusuf Örnek. Ankara: Türkiye Felsefe Kurumu, 2013.

Herzogenrath, Bernd. "Introduction. Film and/as Philosophy: An Elective Affinity?" Film as Philosophy. Der., Bernd Herzogenrath. London: University of Minnesota Press, 2017: vii-xxv.

“Homemade about". Erişim 12 Kasım, 2020. https://www.netflix.com/title/81285512.

Hühnerfeld, Paul. Heidegger. Bir Filozof, Bir Alman. Çev., Doğan Özlem. Ankara: Gündoğan Yayınları, 1994.

Gelven. Michael. Acommentary on Heidegger's Being and Time. Dekalb, IL: Nethern Illinois University Press, 1989.

Grene, Marjorie. Heidegger. London: Bowes \& Bowes, 1957.

Inwood, Michael. A Heidegger Dictionary. Oxford: Blackwell Publishers, 1999.

Larrain, Pablo, Larrain, Juan de Dios ve Mieli, Lorenzo (Producers). (2020). Homemade. [Short film series]. Italy, Chile: Fabula, The Apartment Pictures. Netflix (Distributor).

Magee, Bryan. Büyük Filozoflar Platon'dan Wittgenstein'a Batı Felsefesi. Çev., Ahmet Cevizci. İstanbul: Paradigma Yayınları, 2001.

Martin-Jones, David. "Introduction: Film-Philosophy and a World of Cinemas". Film-Philosophy. 20/1 (2016): 6-23.

Ökten, Kaan H. “Heidegger'in Varlık ve Zaman'daki Ölüm Çözümlemesi”. Cogito (Ölüm: Bir Topografya Sayısı). 40 (2004): 122-157.

Pöggeler, Otto. Martin Heidegger's Path of Thinking. Çev., Daniel Magurshak ve Sigmund J. Barber. Atlantic Highlands: Humanities Press International, 1987.

Safranski, Rüdiger. Bir Alman Üstat: Heidegger. Çev., Ali Nalbant. İstanbul: Kabalcı Yayınevi, 2008.

Schlütz, Daniela M. "Contempoary Quality TV: The Entertaintment Experience of Complex Serial Narratives". Annals of the International Communication Association. 40/1 (2015): 95-124.

Sinnerbrink, Robert. "Techne and poiesis: On Heidegger and Film Theory". Tèchne/Technology: Researching Cinema and Media Technologies Their Development, Use, and Impact. Ed., Annie van den Oever. Amsterdam, Holland: Amsterdam University Press. 2014: 65-80.

Steiner, Georg. Heidegger. Çev., Süleyman Sahra. Ankara: Hece Yayınları, 2003.

Towarnicki, Frederic De. Martin Heidegger Anılar ve Günlükler. Çev., Zeynep Durukal. İstanbul: Yapı Kredi Yayınları, 2002.

Watts, Michael. Heidegger a Guides For Beginner's. London: Hodder and Stoughton, 2001. 


\title{
Being Dasein in Quarantine: A Heideggerian Reading of the Homemade Anthology Series
}

\author{
YASEMIN ÖZKENT* \\ yaseminozkentt@gmail.com \\ ORCID ID: 0000-0002-8617-8429
}

\begin{abstract}
Homemade (2020), a short film anthology, was released by Netflix while the entire world was in quarantine because of the coronavirus pandemic. Seventeen short films shot by different directors narrate independent storylines. They expose existential themes experienced along with the pandemic crisis such as "care (Sorge)", "fear (Furcht)", "anxiety (Angst)", "solitude" and "death" in an artistic manner. The present study argues that Homemade has a narrative structure revealing Martin Heidegger's philosophy as an action. In this respect, the study aims to discover the themes of Heidegger's existential ontology through the example of Homemade. It links Heidegger's ontology with the changes in the emotional and intellectual world of human beings within the crisis environment caused by the pandemic. The short films were evaluated within the framework of the concept of Dasein, which Heidegger established as the way of understanding being. The study analyses the quarantine and the pandemic on the basis of "being-in-the-World" (ln-der-Welt-sein), "being-in concern" (Sorge), and "being-towards-death" (Sein zum Tode), which are the fundamental ends of being Dasein. In this context, it is argued that the quarantine reveals the most personal means of the own being of quotidian Dasein.
\end{abstract}

Keywords: Coronavirus, Martin Heidegger, Dasein, Anthology Series, Homemade

${ }^{*}$ Dr. Lect., Selçuk University, Faculty of Communication. 